\title{
Research of Working Process of Vortex Expansion Machine with Side Channel
}

\author{
Bondar A. V. ${ }^{*}$, Vaneev S. M. \\ ${ }^{1}$ Sumy State University, 2 Rymskogo-Korsakova St., 40007, Sumy, Ukraine
}

\section{Article info:}

Paper received:

The final version of the paper received

Paper accepted online:
November 10, 2017

April 16, 2018

April 20, 2018
*Corresponding Author's Address: artembondar89@gmail.com

\begin{abstract}
At gas distribution stations, a large amount of energy of compressed gases is lost. In such cases, the useful power is obtained with the aid of a turboexpander. The problem is that there is a great need for turboexpanders with a capacity of up to 500-700 kW. For these capacities, the turboexpander with the use of classical turbines turns out to be high-speed, complex, expensive, with a payback period that is more than two years. The solution of this problem is seen in the creation of turboexpander installations based on vortex machines.

A promising type of vortex expansion machines are side channel machines. Results of studies of vortex hydraulic turbines with side channel showed high values of the efficiency.

The goal of this research is study of the working process of vortex expansion machine with side channel by performing a computational experiment in the ANSYS CFX software package.

The results of the research showed that the efficiency of vortex expansion machine with side channel is greater than in vortex expansion machine with peripheral channel (real experiment).
\end{abstract}

Keywords: vortex expansion machine, efficiency, turboexpander, computational experiment, ANSYS CFX, working process.

\section{Introduction}

At gas distribution stations necessarily installed throttle devices, in which a large amount of energy of compressed gases is lost. As a rule, in such cases, the useful power is obtained with the help of a turboexpander.

The problem is that there is a big need for turbo expander with a capacity of 500-700 kW. For these capacities turboexpander with classical turbines turns out to be high-speed, complex, and expensive, with a payback period of more than two years. Key of solving this problem is turboexpander based on vortex machines.

However, it is advisable to use machines of this type not only in turboexpander units. The vortex expansion machines have the potential to be used in various pneumatic devices.

\section{Literature Review}

Literary analysis showed that knows three main types of vortex expansion machines: with peripheral channel, with side channel and with peripheral-side channel. flowing parts of vortex expansion machines can be singlechannel, dual-channel and multichannel.
For compressed fluids, the most studied are vortex expansion machines with peripheral channel $[1-3,6]$. Vortex expansion machines with side channel are practically unexplored.

For incompressible fluids known researches of vortex hydraulic turbines with side channel $[5,6]$. In particular, known the results of experimental tests of vortex machines what working on water. Tests were conducted for the following types of flowing part:

- with side round channel (open and closed types);

- with side rectangular channel of closed type;

- with external peripheral channel.

According to the results of the tests:

- efficiency of vortex machine with side round channel of the closed type with the optimal mode is $54 \%$;

- with a coefficient of fastness $n_{s}=4$, the power of vortex machine with side round channel of a closed type is 7 times greater than the power of an axial partial turbine with the same dimensions and rotational speed;

- efficiency of vortex machine with a rectangular channel is smaller than with a round;

- efficiency of the stage with external peripheral channel in the optimal mode is $13 \%$. 
Thus, in these researches [4] declares the advantage of vortex machines with side channel over machines with external peripheral channel, what working on water.

Also known researches of vortex machines what working on gas.

According to researches of vortex machine with internal peripheral channel [1], the application of this type of flowing part can increase the efficiency of the machine by $25-30 \%$

Vortex machine with external peripheral channel is considered the most technologically and constructively simple. The application of the nozzle in the design of the turbine and the optimization of flowing part allowed to arrange the flow of gas at the inlet section and along the length of flowing part, and to increase the efficiency of the turbine from $10 \%$ to $30-35 \%[2,3]$.

Considering the possibility of a significant increase in the efficiency of vortex machine with peripheral channel, and high values of the efficiency of vortex hydraulic turbines with side channel, it seems advisable to study vortex expansion machines with side channel what working on water.

\section{Research Methodology}

\subsection{Incoming data}

The goal of this research is study of the working process of vortex expansion machine with side channel due a computational experiment. Virtual model (Fig. 1) of vortex expansion machine with side channel based on an experimental model of a vortex pneumatic expansion machine with external peripheral channel [2].
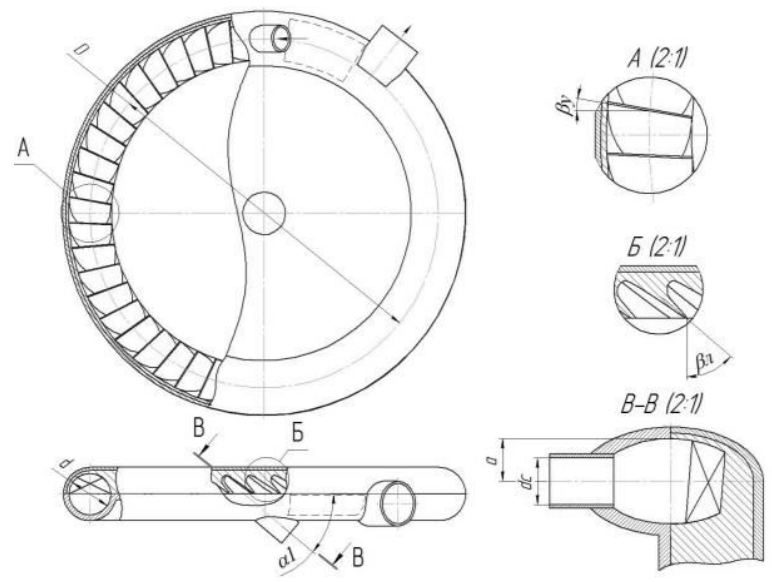

Figure 1 - Constructive scheme of the virtual model

The main geometric parameters of the virtual model were taken from [2], as parameters of modes with a high level of efficiency. Geometric parameters and input data for calculation are presented in Table 1 and Table 2, respectively.
Table 1 - Geometric parameters of the virtual model

\begin{tabular}{|l|c|}
\hline \multicolumn{1}{|c|}{ Name } & Value \\
\hline Average diameter of the impeller, $D$ & $180 \mathrm{~mm}$ \\
\hline $\begin{array}{l}\text { Diameter of meridional intersection of } \\
\text { flow section, } d\end{array}$ & $22 \mathrm{~mm}$ \\
\hline $\begin{array}{l}\text { Angle of blades (the angle between the } \\
\text { edge of the shoulder blade and the axis } \\
\text { perpendicular to the axis of rotation of } \\
\text { impeller) } \beta_{v}\end{array}$ & $10^{\circ}$ \\
\hline $\begin{array}{l}\text { Angle of inclination of blades (angle be- } \\
\text { tween axis of blades and direction, reverse } \\
\text { direction of circumferential speed of im- } \\
\text { peller), } \beta_{l}\end{array}$ & $50^{\circ}$ \\
\hline Number of blades, $z$ & 48 \\
\hline $\begin{array}{l}\text { Angle of gas flow from nozzle to edge of } \\
\text { impeller, } \alpha_{1}\end{array}$ & $40^{\circ}$ \\
\hline Diameter of outlet of nozzle, $d_{s}$ & $12 \mathrm{~mm}$ \\
\hline $\begin{array}{l}\text { The value of displacement of the axis of } \\
\text { nozzle along the width of side channel, } a\end{array}$ & $11 \mathrm{~mm}$ \\
\hline
\end{tabular}

Table 2 - Incoming data

\begin{tabular}{|l|c|c|c|c|c|c|c|}
\hline \multirow{2}{*}{\multicolumn{1}{|c|}{ Parameter }} & \multicolumn{7}{|c|}{ Test mode } \\
\cline { 2 - 8 } & 1 & 2 & 3 & 4 & 5 & 6 & 7 \\
\hline $\begin{array}{l}\text { Total inlet } \\
\text { pressure } \\
P_{1} \cdot 10^{-5}, \mathrm{~Pa}\end{array}$ & 1.53 & 1.87 & 2.16 & 2.58 & 3.25 & 3.87 & 3.60 \\
\hline $\begin{array}{l}\text { Pressure } \\
\text { reduction, } \Pi_{T}\end{array}$ & 1.46 & 1.74 & 1.93 & 2.19 & 2.49 & 2.73 & 2.53 \\
\hline $\begin{array}{l}\text { Total inlet } \\
\text { temperature } \\
T_{1} * \mathrm{~K}\end{array}$ & \multicolumn{7}{|c|}{298} \\
\hline $\begin{array}{l}\text { Rotational } \\
\text { speed, rpm }\end{array}$ & 4000 & \multicolumn{7}{|c|}{5000} \\
\hline Working fluid & \multicolumn{7}{|c|}{} \\
\hline
\end{tabular}

\subsection{Methodology}

Research methodology was taken from [4]. A computational experiment was carried out in the ANSYS CFX software. Verification of the results of a computational experiment in ANSYS CFX with the results of a physical experiment for a vortex expansion machine with external peripheral channel was performed [4]. Verification showed the possibility of using ANSYS CFX for the study of vortex expansion machines.

The calculation process consists of five main stages:

1. Creation of a geometric model (CAD-model).

2. Creation of a virtual model of expansion machine based on a geometric model in a grid generator ANSYS Meshing (number of elements more than 1.5 million).

3. Creation of a virtual model from a grid by imposing settlement conditions. The simulation of turbulent effects was carried out using the SST model. As input data for calculations were taken: total inlet pressure, total inlet temperature and static outlet pressure. The working fluid 
is a viscous compressed air. Roofing of the walls of the flow part $-6.3 \mu \mathrm{m}$.

4. Search for solutions. At this stage, the search for such parameter values in each calculation element is performed so that the entire calculated zone has the maximum correct equation of flows. A solution is considered to be found when the value of the mean-square residual does not exceed $10^{-4}$, as well as no significant fluctuations in the values of the output parameters (torque, mass flow, outlet temperature).

5. Analysis of results of calculation. The calculation of necessary parameters (efficiency, torque, flow, power, temperature, pressure) is organized. Also, we obtain the flow visualization and the distribution of parameters along length of flowing part. The model takes into account the effect of flow in the gap between the cutter and impeller.

Assumption: gaps between housing and impeller is not modeled; no heat exchange with the environment; flow parameters are considered to be evenly distributed over the inlet cross section.

Efficiency during computational experiment is determined by the formula:

$$
\eta=\frac{M_{Z} \cdot \omega}{h_{s} \cdot m}
$$

$M_{z}$ - torque on the shaft of expansion machine, $\mathrm{N} \cdot \mathrm{m}$;

$\omega$ - angular rotational speed of the impeller, $\mathrm{rad} / \mathrm{s}$;

$m$ - mass flow, $\mathrm{kg} / \mathrm{s}$;

$h_{s}$ - specific isenthropic difference of enthalpy, $\mathrm{J} / \mathrm{kg}$.

Specific isentropic difference of enthalpy is determined by the formula:

$$
h_{s}=\frac{k}{k-1} \cdot T_{1}^{*} \cdot R \cdot\left(1-\left(\frac{1}{\Pi_{T}}\right)^{\frac{k-1}{k}}\right),
$$

$k$ - isentrope index of the working fluid;

$R$ - specific gas constant, $\mathrm{J} /(\mathrm{kg} \cdot \mathrm{K})$;

$T_{1}{ }^{*}$ - total inlet temperature, $\mathrm{K}$;

$\Pi_{T}-$ pressure reduction.

Values $h_{s}$ and $\omega$ are determined by the input data, and values $M_{z}$ and $m$ are obtained as a result of computational experiments.

\section{Results and Discussion}

At the first stage, computational experiment was conducted in steady-state mode, on the second - in transient mode.
Table 3 - Results of computational experiment

\begin{tabular}{|c|c|c|c|c|}
\hline \multirow{2}{*}{ Mode } & \multicolumn{4}{|c|}{ Steady-state mode } \\
\cline { 2 - 5 } & $\begin{array}{c}\text { Mass flow, } \\
\mathrm{kg} / \mathrm{s}\end{array}$ & Torque, N.m & $\begin{array}{c}\text { Power, } \\
\mathrm{kW}\end{array}$ & Efficiency \\
\hline 1 & 0.022 & 0.580 & 0.24 & 0.366 \\
\hline 2 & 0.028 & 1.024 & 0.43 & 0.347 \\
\hline 3 & 0.036 & 1.256 & 0.66 & 0.357 \\
\hline 4 & 0.043 & 1.700 & 0.89 & 0.345 \\
\hline 5 & 0.055 & 2.325 & 1.22 & 0.323 \\
\hline 6 & 0.067 & 3.008 & 1.58 & 0.315 \\
\hline 7 & 0.066 & 2.480 & 1.56 & 0.338 \\
\hline
\end{tabular}

Table 4 - Results of real experiment [2]

\begin{tabular}{|c|c|c|c|c|}
\hline \multirow{2}{*}{ Mode } & \multicolumn{4}{|c|}{ Real experiment } \\
\cline { 2 - 5 } & $\begin{array}{c}\text { Mass flow, } \\
\mathrm{kg} / \mathrm{s}\end{array}$ & Torque, $\mathrm{N} \cdot \mathrm{m}$ & $\begin{array}{c}\text { Power, } \\
\mathrm{kW}\end{array}$ & Efficiency \\
\hline 1 & 0.023 & 0.525 & 0.22 & 0.315 \\
\hline 2 & 0.030 & 1.002 & 0.42 & 0.32 \\
\hline 3 & 0.039 & 1.164 & 0.61 & 0.305 \\
\hline 4 & 0.049 & 1.698 & 0.89 & 0.305 \\
\hline 5 & 0.063 & 2.405 & 1.26 & 0.29 \\
\hline 6 & 0.104 & 4.313 & 2.26 & 0.29 \\
\hline 7 & 0.074 & 2.309 & 1.45 & 0.28 \\
\hline
\end{tabular}

As we see, the value of the efficiency of vortex expansion machine with side channel (computational experiment) is higher than efficiency of vortex expansion machine with peripheral channel (real experiment) in all modes. Such results show that vortex expansion machine with side channel is a promising type of such machines.

The data of visualization of flow and distribution of total temperature along the length of flowing part of vortex expansion machine were analysed (Fig. 2-4).

The values of total temperature were taken on a plane between rotor and stator on the average diameter of impeller. Figure 2 shows that on the segment $0^{\circ}-150^{\circ}$ total temperature is not changing, and on the segment $150^{\circ}$ $330^{\circ}$ change in total temperature is much higher. Consequently, the main energy transfer from flow to impeller of vortex expansion machine with side channel occurs on the segment $150^{\circ}-330^{\circ}$ unlike the vortex expansion machine with the peripheral channel [4].

Figures 3-4 present visualization of flows of two modes with different efficiency. As seen, better organized longitudinal-vortex movement along the length of flowing part has more efficiently working process of the vortex expansion machine. 


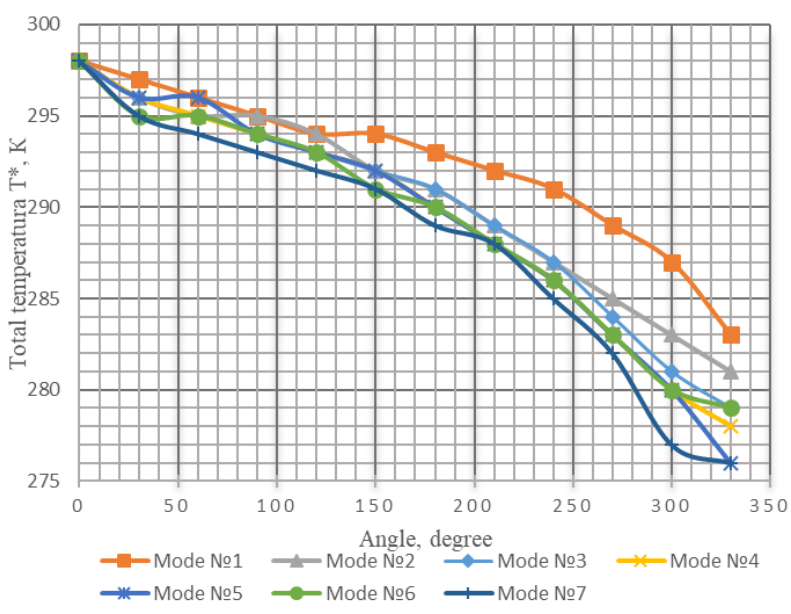

Figure 2 - Distribution of total temperature along the length of flowing part

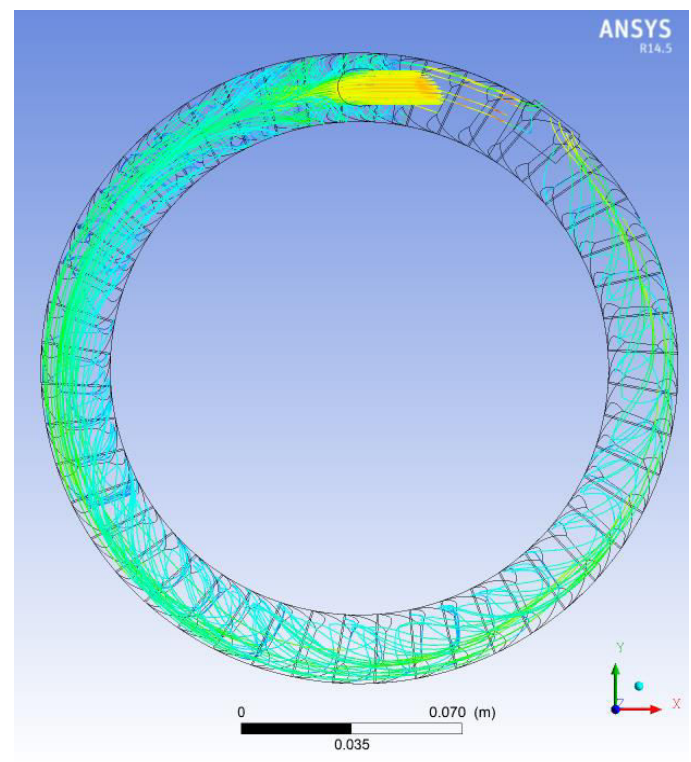

Figure 3 - Visualization of flow of gas in flowing part (mode 1; efficiency 0.366)

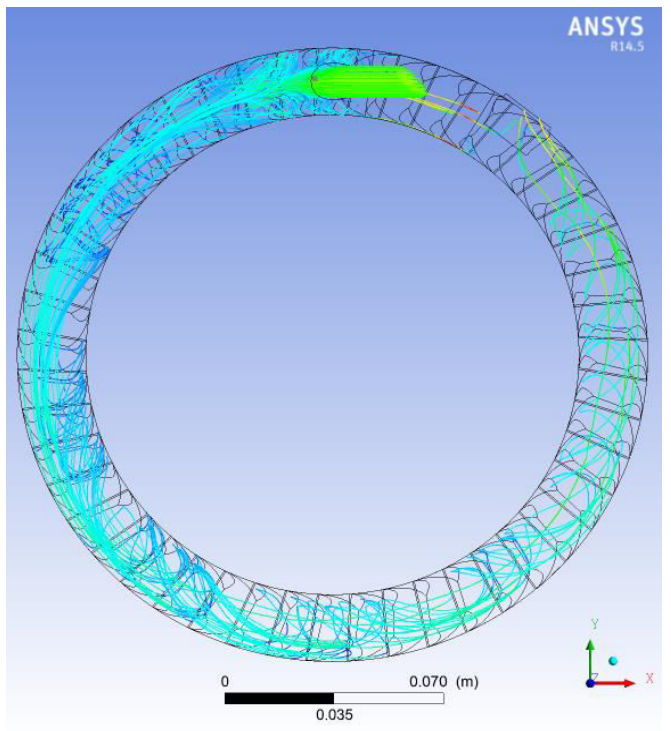

Figure 4 - Visualization of flow of gas in flowing part (mode 6; efficiency 0.315)

\section{Conclusions}

Experiment in steady-state mode in all modes had high values of absolute residuals. However, all of them are localized in the area of the shut-off, what indicates the complex and uncertain nature of flow in this area of flowing part.

Experiment in transient mode failed, solutions were not found on all modes. Experiment in transient mode in essence should be the most accurate and closest to the real work process. In addition, the results of the experiment in steady-state mode are input data for the experiment in transient mode. Failure to obtain a solution in a transient mode indicates that results of experiment in steady-state mode need to be confirmed by a real experiment.

\section{References}

1. Sergeev, V. N. (1986). Development vortex actuator with an internal peripheral channel and research of the effect of gasdynamic and geometric parameters of its effectiveness. Dissertation Candidate of Engineering Sciences, Moscow.

2. Vaneev, S. M. (1986). Development and research vortex pneumo drive with an external peripheral channel and nozzle device. Dissertation Candidate of Engineering Sciences, Moscow.

3. Staroverov, K. V. (1990). Improvement and research of vortex machine with a peripheral channel in pneumo drive mode. Dissertation Candidate of Engineering Sciences, Moscow.

4. Vaneev, S. M., \& Miroshnichenko, D. V. (2015). Research vortex expansion machine with external peripheral channel using virtual test rig. Journal of Engineering Sciences, Vol. 2, Issue 2, pp. B10-B12.

5. Cheban, V. G. (2003). The small-sized rotational turbine as a driving of hydrodynamic purifier of thick liquids. Dissertation Candidate of Engineering Sciences, Sumy State University, Sumy.

6. Baybakov, O. V. (1981). Vortex hydraulic machines. Moscow, Machinery. 


\title{
Дослідження робочого процесу вихрової розширювальної машини з бічним каналом
}

\author{
Бондар А. В. , Ванєєв С. М. \\ ${ }^{1}$ Сумський державний університет, вул. Римського-Корсакова, 2, 40007, м. Суми, Україна
}

\begin{abstract}
Анотація. На газорозподільних станціях втрачається велика кількість енергії стислих газів. В таких випадках корисну потужність отримують за допомогою турбодетандера. Проблема полягає в тому що, $\epsilon$ велика потреба в турбодетандерах потужністю до 500-700 кВт. Для цих потужностей турбодетандер при використанні класичних турбін виходить високообертовим, складним, дорогим, з терміном окупності, який становить більше двох років. Вирішення цієї проблеми вбачається у створенні турбодетандерних установок на основі вихрових машин.

Перспективним типом вихрових розширювальних машин є машини з бічним каналом, так як відомі дослідження, результати яких показали високі значення ККД вихрових гідравлічних турбін з бічним каналом.

Метою даної статті є дослідження робочого процесу вихрової розширювальної машини з бічним каналом шляхом проведення числового експерименту в програмному комплексі ANSYS CFX.

Результати досліджень показали, що значення ККД вихрової розширювальної машини з бічним каналом більше ніж у вихрової розширювальної машини з периферійним каналом (реальний експеримент).
\end{abstract}

Ключові слова: вихрова розширювальна машина, коефіцієнт корисної дії, турбодетандер, числовий експеримент, ANSYS CFX, робочий процес. 